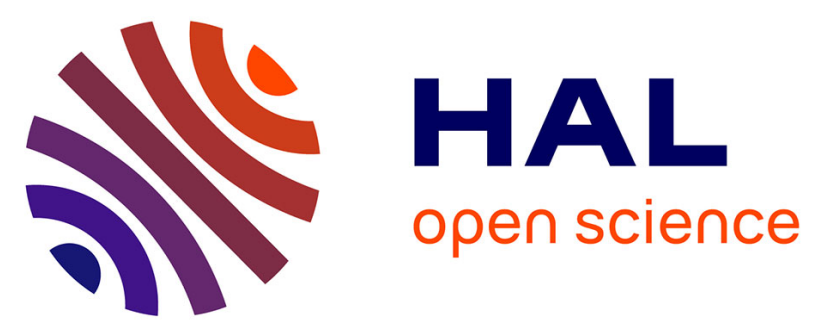

\title{
Modulation of cellular fate of vinyl triarylamines through structural fine tuning: to stay or not to stay in the mitochondria?
}

Laura Fourmois, Florent Poyer, Aude Sourdon, Delphine Naud-Martin, Sounderya Nagarajan, Rahima Chennoufi, Eric Deprez, Marie-Paule

Teulade-Fichou, Florence Mahuteau-Betzer

\section{To cite this version:}

Laura Fourmois, Florent Poyer, Aude Sourdon, Delphine Naud-Martin, Sounderya Nagarajan, et al.. Modulation of cellular fate of vinyl triarylamines through structural fine tuning: to stay or not to stay in the mitochondria?. ChemBioChem, 2021, 22 (14), pp.2457-2467. 10.1002/cbic.202100168. hal-03333512

\section{HAL Id: hal-03333512 \\ https://hal.science/hal-03333512}

Submitted on 3 Sep 2021

HAL is a multi-disciplinary open access archive for the deposit and dissemination of scientific research documents, whether they are published or not. The documents may come from teaching and research institutions in France or abroad, or from public or private research centers.
L'archive ouverte pluridisciplinaire HAL, est destinée au dépôt et à la diffusion de documents scientifiques de niveau recherche, publiés ou non, émanant des établissements d'enseignement et de recherche français ou étrangers, des laboratoires publics ou privés. 


\title{
Modulation of cellular fate of vinyl triarylamines through structural fine tuning: to stay or not to stay in the mitochondria?
}

\author{
Laura Fourmois, ${ }^{[a, b]}$ Florent Poyer, ${ }^{[a, b]}$ Aude Sourdon, ${ }^{[a, b]}$ Delphine Naud-Martin, ${ }^{[a, b]}$ Sounderya \\ Nagarajan, ${ }^{[a, b]}$ Rahima Chennoufi, ${ }^{[c]}$ Eric Deprez, ${ }^{[c]}$ Marie-Paule Teulade-Fichou, ${ }^{*[a, b]}$ Florence \\ Mahuteau-Betzer ${ }^{*[a, b]}$
}

[a] Dr. L. Fourmois, Dr. F. Poyer, Dr. A. Sourdon, D. Naud-Martin, Dr. S. Nagarajan, Dr. M.-P. Teulade-Fichou, Dr. F. Mahuteau-Betzer Institut Curie, Université PSL, CNRS UMR9187, Inserm U1196, Chemistry and Modelling for the Biology of Cancer F-91400 Orsay, France

E-mail: mp.teulade-fichou@curie.fr; florence.mahuteau@curie.fr

[b] Dr. L. Fourmois, Dr. F. Poyer, Dr. A. Sourdon, D. Naud-Martin, Dr. S. Nagarajan, Dr. M.-P. Teulade-Fichou, Dr. F. Mahuteau-Betzer Université Paris-Saclay, CNRS UMR9187, Inserm U1196, Chemistry and Modelling for the Biology of Cancer F-91400 Orsay, France

[c] Dr. R. Chennoufi, Dr. E. Deprez

ENS Paris-Saclay, Université Paris-Saclay, CNRS UMR8113, IDA FR3242, Laboratory of Biology and Applied Pharmacology (LBPA) F-91190, Gif-sur-Yvette, France

Supporting information for this article is given via a link at the end of the document

\begin{abstract}
Mitochondria is involved in many cellular pathways and dysfunctional mitochondria are linked to various diseases. Hence efforts have been driven to design mitochondria-targeted fluorophores for monitoring the mitochondria status. However, the factors that govern the mitochondria-targeted potential of dyes are not well-understood. In this context, we synthesized analogues of the TP-2Bzim probe belonging to the vinyltriphenylamine (TPA) class and already described for its capacity to bind nuclear DNA in fixed cells and mitochondria in live cells. These analogues (TP1Bzim, TP ${ }^{n}$-2Bzim, TP ${ }^{1+}$-2Bzim, TN-2Bzim) differ by the cationic charge, the number of vinylbenzimidazolium branches and the nature of the triaryl core. Using microscopy, we demonstrated that the cationic derivatives accumulate in mitochondria but do not reach mtDNA. Under depolarisation of the mitochondrial membrane, TP2Bzim and TP $^{1+}$-2Bzim translocate to the nucleus in direct correlation with their strong DNA affinity. This reversible phenomenon emphasizes that these probes can be used to monitor $\Delta \Psi_{\mathrm{m}}$ variations
\end{abstract}

\section{Introduction}

Fluorescent probes are powerful tools for cellular imaging. In the last decades, there has been a strong interest in the design of organelle-targeted fluorescent probes as well as fluorophores that are responsive to cellular changes. ${ }^{[1]}$ Among the numerous chemical probes developed, those targeting mitochondria are particularly attractive thanks to the central role of this organelle in the regulation of the cellular death. Indeed, mitochondria is not only the power unit of the cell but is also involved in apoptosis ${ }^{[2]}$ and in diverse cellular pathways such as intracellular calcium signaling and reactive oxygen species production. As dysregulation of apoptosis can lead to several disorders such as cancer, ${ }^{[3]}$ neurodegenerative,${ }^{[4]}$ autoimmune or ischemic diseases, ${ }^{[5]}$ the status of mitochondria can be used as a diagnosis tool. In this context, a number of probes have been designed to monitor the production of $\mathrm{ROS}^{\left[{ }^{[6]}\right.}$ the mitochondrial $\mathrm{pH}$ changes ${ }^{[7]}$ or the mitochondria membrane potential variation $\left(\Delta \Psi_{\mathrm{m}}\right)^{\left[{ }^{[8]}\right.}$.The latter, in particular, is a key parameter of the mitochondrial function and is characterized by a highly negative value $\left(\Delta \Psi_{\mathrm{m}}=-180 \mathrm{mv}\right)$, which results from the charge imbalance across the inner mitochondrial membrane generated by the oxidative phosphorylation chain. Since membrane permeabilization and $\Delta \Psi_{\mathrm{m}}$ are intrinsically connected and related to apoptosis, $\Delta \Psi_{\mathrm{m}}$ can be used as indicator of apoptosis and necrosis. ${ }^{[9]}$ Therefore the design of $\Delta \Psi_{\mathrm{m}}$ responsive probes is of great interest for imaging cellular death as well as for diagnosis and chemotherapeutic intervention.

Most of the mitochondria-targeted fluorescent probes ${ }^{[10]}$ are lipophilic cations characterized by a delocalized charge (DLCs) whose uptake is driven by the electrostatic force developed by the negative gradient across the inner mitochondrial membrane. ${ }^{[11]}$ As a result the concentration of DLCs can be up to $100-1000$ times higher in the mitochondrial matrix than in the cytosol. ${ }^{[12]}$ Nonetheless owing to the very active metabolism of ions exchanges due to the electron transport chain, the trapped DLCs may move back and forth across the mitochondrial membranes depending on (transient) variation of the membrane potential that in turn is directly influenced by the mitochondria health status. For instance, conventional fluorescent cationic stains such as Rhodamines (e.g. Rhodamine 123 and analogues), are readily sequestered into mitochondria and are released to the cytosol when $\Delta \Psi_{m}$ dissipates. Therefore, this class of dyes cannot stain mitochondria in fixed (dead) cells since the fixation treatments induce massive mitochondrial membrane depolarization. Conversely, MitoTracker ${ }^{\mathrm{TM}}$ probes (a family comprised of rosamine and cyanine derivatives) are able to stain mitochondria in both fixed and live cells. ${ }^{[13]}$ This particular behaviour results from the presence of one or several chlorobenzyl groups on the dye aromatic skeletons which induce covalent reaction with the thiol functions of proteins in mitochondria making the relocalisation of MitoTracker probes impossible and therefore independent of variation of $\Delta \Psi_{\mathrm{m}}$. On the other hand, variation in $\Delta \Psi_{\mathrm{m}}$ can be signalled by specific probes although only a handful of those are available. The most popular is the carbocyanine dye $\mathrm{JC}-1$, which ${ }^{[14]}$ accumulates in the mitochondrial matrix where it forms red-emissive aggregates whereas upon membrane depolarization its concentration 
decreases lead to the formation of green-emitting monomers. Thus monitoring of $\Delta \Psi_{\mathrm{m}}$ by $\mathrm{JC}-1$ relies on the ratiometric emission between the monomers and the aggregates. However, although JC-1 is widely used, its uptake, concentration in the extracellular medium and incubation time need to be carefully controlled in order to get a clear response depending on its aggregation or disaggregation status. ${ }^{[8]}$ To circumvent this drawback and to provide efficient imaging tools for mitochondria status monitoring, recent reports proposed new probes based on alternative strategies such as the relocalization from mitochondria to other organelles under mitochondria membrane depolarization. ${ }^{[15]}$

In this context, we undertook to explore further the properties of TPA dyes, a series that we pioneered several years ago and that possess remarkable fluorescence characteristics for cellular bioimaging. ${ }^{[16]}$ TPA dyes, bearing two or three cationic branches were initially designed for nonlinear (two-photon) absorption and were shown to display high photo-stability, while being live-cellpermeant. Furthermore these dyes are fluorogenic upon binding to the DNA minor groove, which switches on their fluorescence with dramatic quantum yield enhancement. ${ }^{[16 b]}$ Accordingly, in fixed cells TPA-induce bright and stable nuclear DNA staining with excellent contrast whereas in live cells their behaviour is radically different, ${ }^{[17]}$ as they remain sequestered in mitochondria Most interestingly upon light excitation either visible (488 nm, 1photon absorption) or NIR (760-860 nm, 2-photon absorption), ${ }^{[18]}$ TPA leave the mitochondria and rapidly translocate to the nucleus. This phenomenon is concomitant with ROS production and apoptosis. Therefore, on one hand TPA rank amongst the brightest DNA markers developed so far in fixed cells ${ }^{[16 b]}$ and on the other hand, act as photoactivatable mitochondria-targeted proapoptotic agents in live cells. ${ }^{[17-19]}$

However, the structural determinants influencing the mitochondrial sequestration as well as the capacity to translocate out of the mitochondria in absence of light activation and in particular the dependence with regard to the mitochondrial membrane potential have not been examined in detail. In addition, the question of whether TPA mitochondrial localisation is in part driven by mtDNA binding remained unanswered. This question in particular is of broad interest as several studies have reported that cationic dyes could target secondary DNA structures in mtDNA but without providing direct evidence. ${ }^{[20]}$ Furthermore finding new labels with a variety of excitation wavelengths for visualizing mtDNA is also of great interest as mentioned in a recent report. ${ }^{[21]}$ Therefore, stimulated by the recent impetus for dye targeting mitochondria, it was decided to address these questions through molecular engineering of the TP-2Bzim compound (Figure 1), which represents the best candidate of the TPA series in terms of brightness and DNA binding affinity.

Hence in the present work, we report on structural modifications of the reference compound TP-2Bzim devoted to modulate the lipophilic /cationic charge balance, which led to four new Bzim derivatives. Firstly, we modified the number of charges through the synthesis of the neutral analogue TP $^{n}$-2Bzim and the monocationic analogue $\mathbf{T P}^{1+}$-2Bzim then the number of vinyl branches was reduced affording the monobranched compound TP $^{1+}$-1Bzim (Figure 1). Finally, the triphenylamine core has been replaced by its trinaphtylamine counterpart providing the more lipophilic analogue TN-2Bzim. This core modification was previously shown to strongly improve the two-photon absorption properties due to the higher electron-richness of the TNA core. $^{[22]}$ Next we studied the photophysical properties and the cellular imaging of this new panel of dyes in order to determine the physico-chemical parameters responsible of their cellular behaviour. In the whole, the systematic comparison of the dyes in fixed and live cells indicated that subtle structural changes strongly affect the partition between mitochondria and nucleus, the translocation dynamics and presumably the initial mitochondrial membrane localisation.

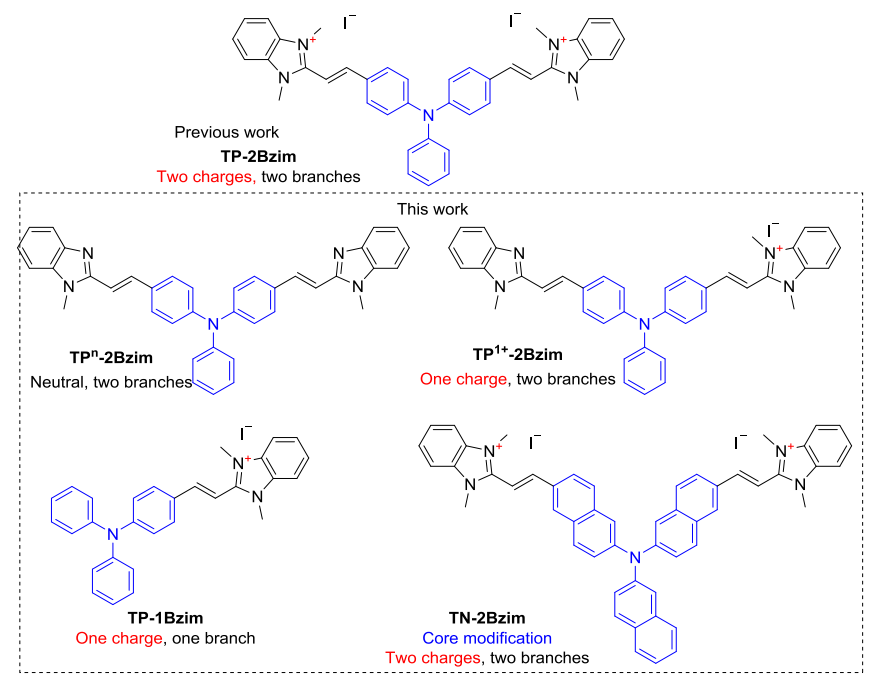

Figure 1. Chemical structures of TP-1Bzim, TP-2Bzim, TP ${ }^{n}$-2Bzim, TP ${ }^{1+}$ 2Bzim, TN-2Bzim

\section{Results and Discussion}

\section{Design and synthesis}

TP-1Bzim was prepared following the same procedure reported for the synthesis of TP $^{n}$-2Bzim and TP-2Bzim: ${ }^{[16 b]}$ a Wittig reaction between the mono-formyl triphenylamine and the $(\mathrm{N}$ methyl benzimidazole)-methyltriphenylphosphonium chloride afforded compound 1 in $47 \%$ yield, subsequent methylation allowed the formation of TP-1Bzim in quantitative yield. The monocationic compound TP $^{1+}$-2Bzim has been synthesized in two steps as follows: a mono Wittig reaction was performed on the commercially available precursor 4,4'-diformyltriphenylamine to afford the monosubstituted -aldehyde 2 in high yield (84\%). This intermediate compound was then converted into $\mathbf{T P}^{1+}$ 2Bzim by a Knoevenagel reaction using 1,2,3 trimethylbenzimidazolium iodide (see Scheme 1). The synthesis of TN-2Bzim was also achieved in two-steps as follows: the commercially available 2-naphtylamine and 6-bromo-2naphtaldehyde was coupled via a Buchwald-Hartwig amination to give the 6,6' diformyltrinaphtylamine 3 in a moderate yield (38\%). This step involves two coupling reactions: the first one between 2-naphtylamine and 6-bromo-2-naphtaldehyde and the second one between the resulting dinaphtylamine intermediate of lower reactivity and a second equivalent of 6-bromo-2naphtaldehyde. A Knoevenagel reaction between dialdehyde 3 and 1,2,3-trimethylbenzimidazolium iodide afforded TN-2Bzim (see Scheme 1) in a moderate yield (31\%). 


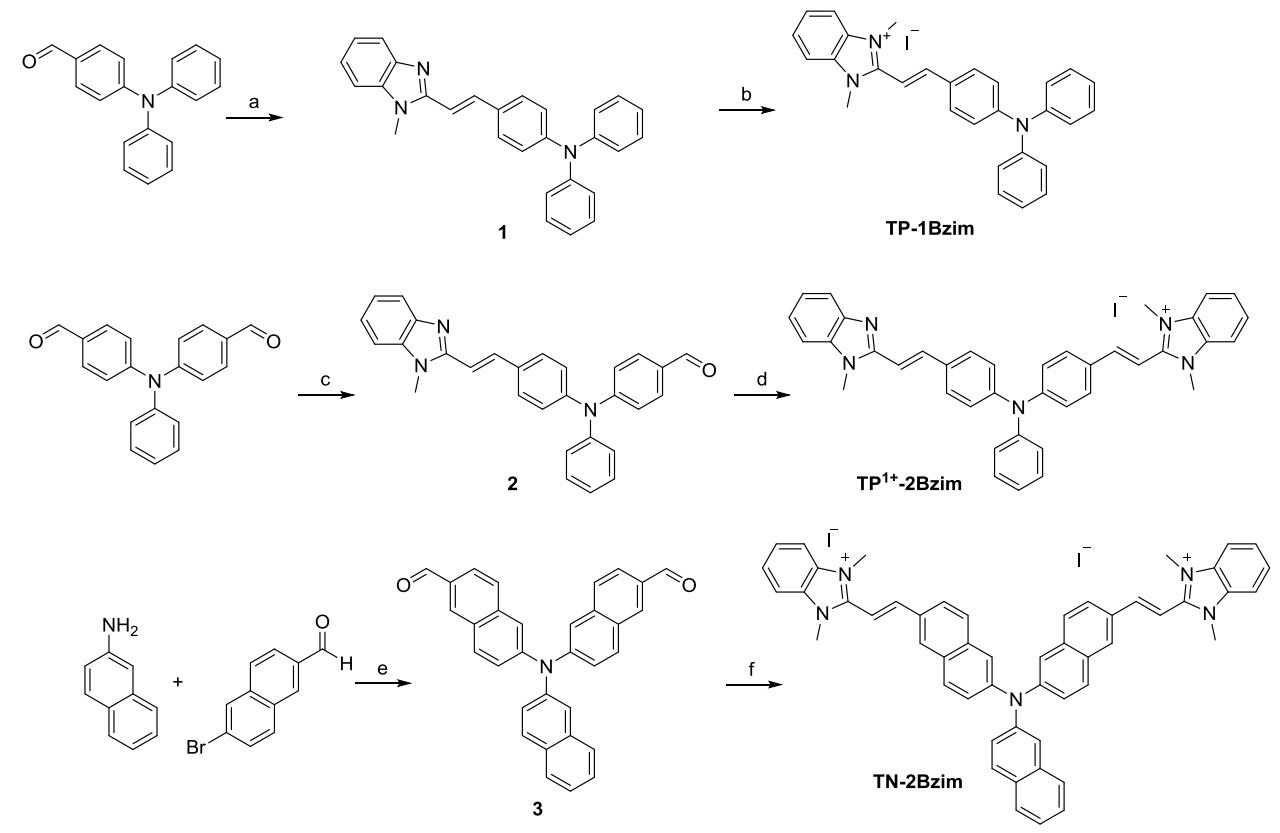

Scheme 1. Synthesis of TP-1Bzim, TP ${ }^{1+}$-2Bzim and TN-2Bzim. Reagents and conditions: (a) ( $N$-methyl benzimidazole)-methyltriphenylphosphonium chloride , $\mathrm{DBU}, \mathrm{THF} / \mathrm{EtOH}$, r.t., $18 \mathrm{~h}, 47 \%$; (b) $\mathrm{Mel}, \mathrm{DMF}, 60^{\circ} \mathrm{C}, 100 \%$; (c) ( $\mathrm{N}$-methyl benzimidazole)-methyltriphenylphosphonium chloride , DBU, THF/EtOH, r.t., $18 \mathrm{~h}$ $84 \%$; (d) 1,2,3-trimethyl-1Hbenzo[d]imidazole-3-ium iodide, piperidine, EtOH, $80^{\circ} \mathrm{C}, 18 \mathrm{~h}, 38 \%$; (e) $\mathrm{Pd}(\mathrm{OAc})_{2}, \mathrm{P}(t-\mathrm{Bu})_{3}, \mathrm{Cs}_{2} \mathrm{CO}_{3}$, toluene, reflux, $48 \mathrm{~h}, 38 \%$; (f) 1,2,3-trimethyl-1 1 benzo[d]imidazole-3-ium iodide, piperidine, $\mathrm{EtOH}, 80^{\circ} \mathrm{C}, 15 \mathrm{~h}, 31 \%$.

\section{Photophysical properties}

The optical properties of TP-1Bzim, TP ${ }^{n}$-2Bzim, TP ${ }^{1+}$-2Bzim, TN-2Bzim were characterized in glycerol and in buffer $(\mathrm{pH} 7.2)$ with or without DNA at room temperature (Table 1). The properties of the TP-2Bzim are provided here for comparison. All derivatives show a maximal absorption between 411 and 450 $\mathrm{nm}$ in aqueous buffer and strong molar absorption coefficients between 21200 to $42500 \mathrm{M}^{-1} \cdot \mathrm{cm}^{-1}$. The four cationic compounds are poorly fluorescent in aqueous buffer with quantum yield ranging from 0.006 down to $<0.001$, in consistency with our previous reports. Conversely the neutral derivative $\mathbf{T P}^{\mathrm{n}}$-2Bzim exhibits substantially higher emission (5fold that of the monocationic TP $\left.^{1+}-2 B z i m\right)$. This illustrates the polarity effect of water towards highly polar excited states (push pull) and is consistent with the lower polarity of the neutral compound. Since this compound series is known to be sensitive to the environment viscosity, the optical properties were also assessed in glycerol (see Figure S1). In all cases, the dye fluorescence is strongly enhanced in glycerol with a maximum emission between 520 to $637 \mathrm{~nm}$ and with quantum yields from 0.08 to 0.58 (Table 1). As shown previously, the enhancement of fluorescence in glycerol is attributed to reduced rotational motions of the aromatic rings around the vinylic bond inducing inhibition of the non-radiative de-excitation pathway. As expected, the addition of charges, from TP $^{\mathrm{n}}$-2Bzim to TP-2Bzim increases the transfer of charges between the donor core (TP/TN) and the terminal acceptor Bzim groups, leading to a bathochromic shift of the emission (from $561 \mathrm{~nm}$ to $620 \mathrm{~nm}$ in water, from $520 \mathrm{~nm}$ to $602 \mathrm{~nm}$ in glycerol). The extension of the conjugation for TN-2Bzim as compared to TP-2Bzim also leads to an expected bathochromic shift in the absorption wavelength but also in the emission wavelength (from 620 to $638 \mathrm{~nm}$ in buffer and from 585 to $614 \mathrm{~nm}$ in glycerol).
Since TP-2Bzim is a potent DNA-interactive compound that binds in the minor groove of AT-rich duplex DNA with submicromolar affinity, ${ }^{[15 b]}$ it was of interest to evaluate the impact of the structural modifications on the dye /DNA interaction. To this end UV and fluorimetric titrations were performed using a 14-mer palindromic sequence $\left(5^{\prime}\right.$. CGCGAAATTTCGCG, Drew AT) forming a short duplex mimicking AT-rich B-DNA. For all compounds, absorption is strongly decreased upon addition of DrewAT with a red-shift of the maxima for $\mathbf{T P}^{1+}$-2Bzim and $\mathbf{T N}$-2Bzim indicating a decrease in polarity of the dye environment arising from interaction with DNA (Table 1, Figure 2). Worth noting is the presence of an isosbestic point in the case of $\mathbf{T P}^{1+}$-2Bzim (500 $\mathrm{nm}$, Figure 2A) similarly to that observed for TP-2Bzim (Figure $2 B$ ) indicating the presence of two species in equilibrium whereas none is observed for the neutral, the monobranched and the trinaphtyl derivatives (Figure 2A). On the opposite, the variation in emission strongly differs from one compound to another: TP $^{1+}$-2Bzim retains the fluorescence turn-on property of TP-2Bzim and displays a remarkable 45-fold increase in quantum yield at saturation in DrewAT (Figures 2A and B). As well in both cases the emission is blue-shifted as has been observed for certain DNA dyes, ${ }^{[23]}$ and is attributed to changes in the dipole moment upon excitation. The monobranched monocationic analogue TP-1Bzim shows a significantly lower fluorescence enhancement (4.5) denoting the importance of the 2 Bzim branches moiety for the fluorescence increase. In contrast the fluorescence of $\mathbf{T P}^{\mathrm{n}}$-2Bzim is strongly quenched upon adding DrewAT (Figure 2A) 
Table 1. Linear optical properties of vinyltriarylamine derivatives in $\mathrm{pH} 7.2$ cacodylate buffer with or without DrewAT and in glycerol.

\begin{tabular}{|c|c|c|c|c|c|c|}
\hline & Solvent & $\begin{array}{l}\lambda_{\mathrm{exc}} \\
\lambda_{\mathrm{em}}{ }^{[\mathrm{b}]}\end{array}$ & $\varepsilon^{[c]}$ & $\Phi_{F}^{[d]}$ & $\Phi_{\mathrm{F}} \times \varepsilon$ & $\begin{array}{r}\sigma^{[\varepsilon]} \\
\left(\lambda_{\text {abs }}\right)\end{array}$ \\
\hline \multirow{3}{*}{ TP-1Bzim } & Buffer ${ }^{[e]}$ & $\begin{array}{l}411 \\
598\end{array}$ & 31560 & $\begin{array}{l}<0 \\
005\end{array}$ & & - \\
\hline & DrewAT & $\begin{array}{l}411 \\
590\end{array}$ & 12100 & 0.02 & 242 & - \\
\hline & Glycerol & $\begin{array}{l}422 \\
579\end{array}$ & 27700 & 0.08 & 2216 & - \\
\hline \multirow{3}{*}{$T^{n}$-2Bzim } & Buffer & $\begin{array}{l}440 \\
561\end{array}$ & 29770 & 0.03 & & - \\
\hline & DrewAT & $\begin{array}{l}435 \\
560\end{array}$ & 12000 & 0.02 & 240 & - \\
\hline & Glycerol & $\begin{array}{l}423 \\
520\end{array}$ & 52100 & 0.58 & 30218 & - \\
\hline \multirow{3}{*}{$\mathrm{TP}^{1+}-2 \mathrm{Bzim}$} & Buffer & $\begin{array}{l}444 \\
610\end{array}$ & 21200 & 0.006 & & - \\
\hline & DrewAT & $\begin{array}{l}472 \\
575\end{array}$ & 16250 & 0.33 & 5363 & - \\
\hline & Glycerol & $\begin{array}{l}438 \\
575\end{array}$ & 33340 & 0.09 & 3000 & - \\
\hline \multirow{3}{*}{ TN-2Bzim } & Buffer & $\begin{array}{l}450 \\
638\end{array}$ & 42910 & 0.006 & & - \\
\hline & DrewAT & $\begin{array}{l}470 \\
620\end{array}$ & 20750 & 0.01 & 207 & $\begin{array}{l}2500 \\
(830)\end{array}$ \\
\hline & Glycerol & $\begin{array}{l}450 \\
614\end{array}$ & 44680 & 0.08 & 3574 & - \\
\hline \multirow{3}{*}{ TP-2Bzim $^{[f]}$} & Buffer & $\begin{array}{l}432 \\
620\end{array}$ & 42500 & $<0.001$ & & - \\
\hline & DrewAT & $\begin{array}{l}476 \\
585\end{array}$ & 44400 & 0.54 & 23976 & $\begin{array}{l}1080 \\
(840)\end{array}$ \\
\hline & Glycerol & $\begin{array}{l}448 \\
602\end{array}$ & 40400 & 0.35 & 14140 & - \\
\hline
\end{tabular}

[a] Cacodylate buffer: $10 \mathrm{mM}$ sodium cacodylate buffer $(\mathrm{pH} 7.2,100 \mathrm{mM}$ $\mathrm{NaCl}$ ); DrewAT: $10 \mathrm{~mol}$ equiv of DrewAT. [b] $\lambda_{\text {abs: }}$ : maximum absorption wavelength $(\mathrm{nm}) ; \lambda_{\mathrm{em}}$ : maximum emission wavelength $(\mathrm{nm})$. [c] $\varepsilon$ : molar absorption coefficient $\left(\mathrm{mol}^{-1} \cdot \mathrm{L} \cdot \mathrm{cm}^{-1}\right)$. [d] $\Phi_{\mathrm{F}}$ : fluorescence quantum yields were measured using rhodamine 101 in ethanol as reference. [e] $\sigma: 2 P A$ cross section (GM). [f] data from ref. ${ }^{[16 b]}$

whilst the fluorescence emission of TN-2Bzim is poorly affected (2-fold increase) (Figure 2A). The titration curves resulting from the fluorescence variations (Figure S2, supporting information) allowed to determine 1:1 binding for $\mathbf{T P}^{1+}$-2Bzim and TP-1Bzim with $\mathrm{Kd}$ values in the submicromolar range showing a strong association although 100-fold lower than that of the parent biscationic TP-2Bzim ${ }^{[15 b]}$ as expected. For the neutral and TNA derivative the weak variations observed reveal a poor association, between the dyes and the DNA which is likely nonspecific and could correspond to external binding or partial insertion in grooves. In particular, in the case of TN-2Bzim although it harbors the same biscationic charge as TP-2Bzim, it is likely that the $3 \mathrm{D}$ geometry of the trinaphtyl core is too bulky and therefore not appropriate to fit in the minor-groove contrary to what was shown for TP-2Bzim. ${ }^{[15 b]}$ This indicates that although the electrostatic forces contribute significantly to DNA binding, other weak forces resulting from the tight fit of the two vinyl branches of TP-2Bzim and TP $^{1+}$-2Bzim into the AT-rich minor groove seems to be a strong determinant of the interaction.

Finally since high two-photon cross-section have been reported for neutral trinaphtylamines (TNA) ${ }^{[22]}$, the two-photon absorption spectra of TN-2Bzim was measured in DNA by the TPEF (twophoton excitation fluorescence) method (see Figure S3, supporting information). The 2PA spectrum shows a very high cross-section ( $\sigma=2500 \mathrm{GM}$ at $830 \mathrm{~nm}$ ), which is two-fold higher than that of TP-2Bzim $(\sigma=1080 \mathrm{GM}$ at $840 \mathrm{~nm}$ ) thus confirming the advantage of the TN core for optimizing two-photon absorption properties. ${ }^{[22]}$ However, due to its lower fluorescence quantum yield and its low binding to DNA, TN-2Bzim displays a lower two-photon brightness in presence of DNA $(\sigma \times \Phi F=250)$ than its TP counterpart $(\sigma \times \Phi F=583)$. For the same reason the one-photon brightness of this compound is also significantly impacted (Table 1). 

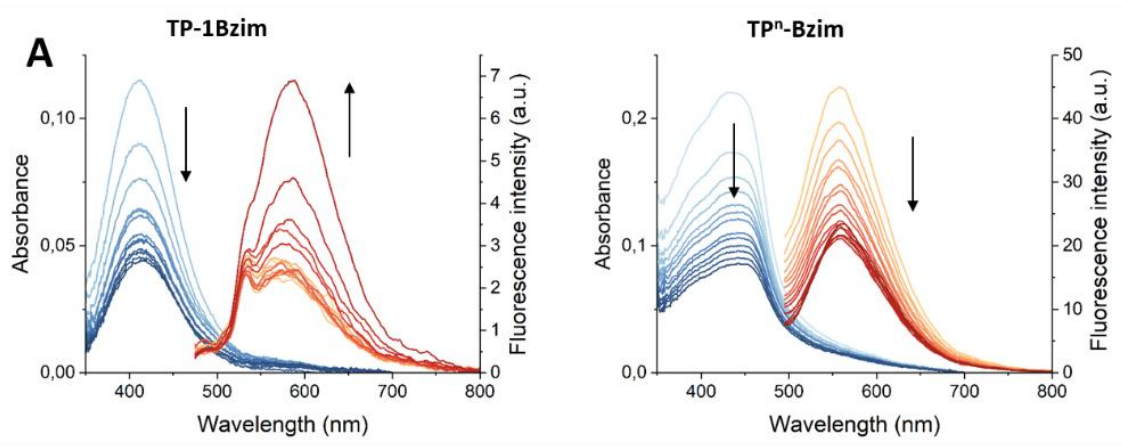

B
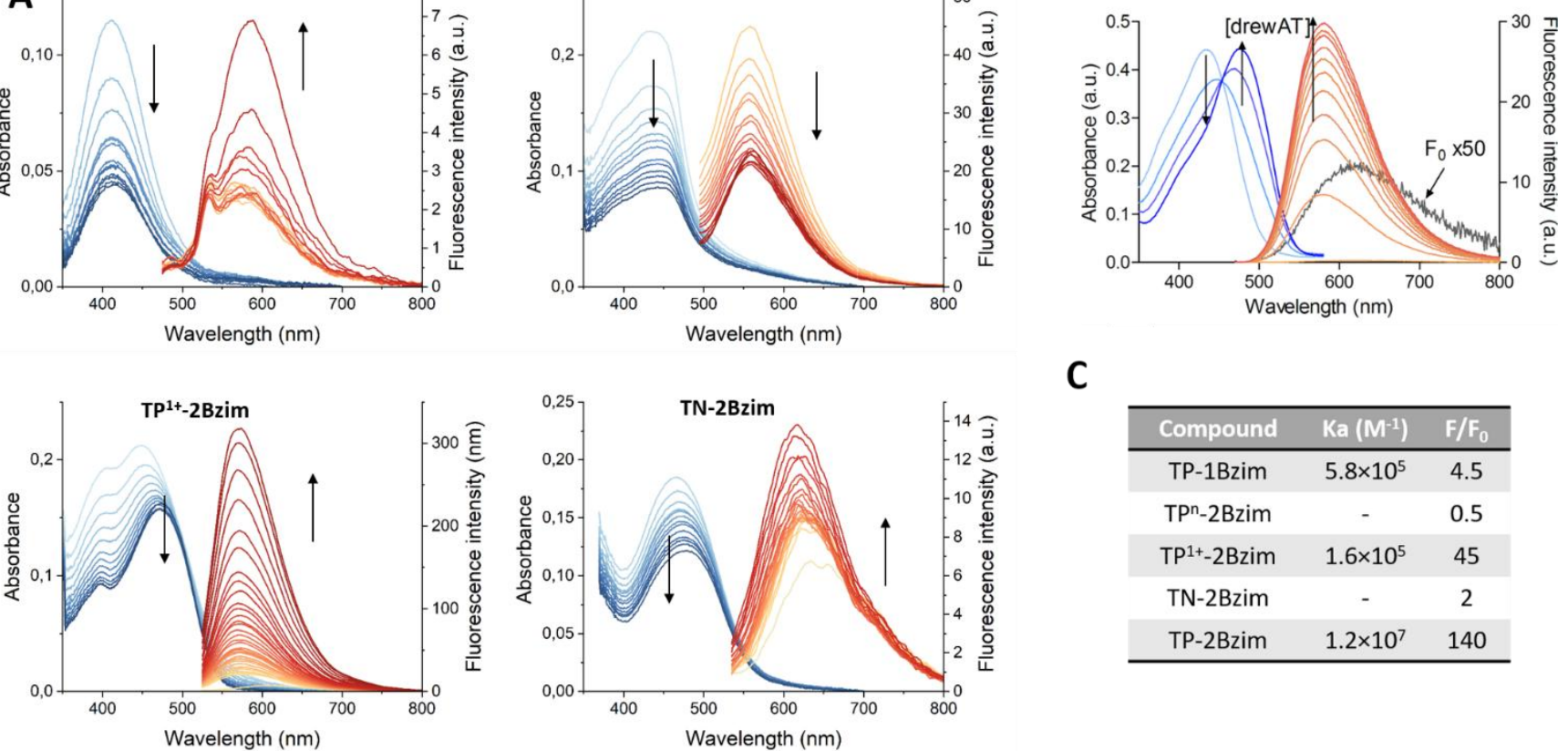

C

\begin{tabular}{ccc}
\hline Compound & $\mathrm{Ka}\left(\mathrm{M}^{-1}\right)$ & $\mathrm{F} / \mathrm{F}_{0}$ \\
\hline TP-1Bzim & $5.8 \times 10^{5}$ & 4.5 \\
\hline $\mathrm{TP}^{\mathrm{n}}$-2Bzim & - & 0.5 \\
$\mathrm{TP}^{1+}$-2Bzim & $1.6 \times 10^{5}$ & 45 \\
\hline $\mathrm{TN}-2 \mathrm{Bzim}$ & - & 2 \\
\hline TP-2Bzim & $1.2 \times 10^{7}$ & 140 \\
\hline
\end{tabular}

Figure 2. Absorption (in blue) and fluorescence spectra (in red) of $\mathrm{A}$ ) new compounds at $10 \mu \mathrm{M}$ and $1 \mu \mathrm{M}$, respectively and B) TP-2Bzim at $10 \mu \mathrm{M}$ and $0.25 \mu \mathrm{M}$ respectively (already described in ref 22), upon addition of DrewAT (sequence: 5'-CGCG-AAATTT-TCGCG-3') (0-20 $\mu M$ ) in sodium cacodylate buffer 10 mM at pH 7.2, NaCl $400 \mathrm{mM}\left(\lambda_{\text {exc }}=465 \mathrm{~nm}\right.$ for TP-1Bzim, $\lambda_{\text {exc }}=485 \mathrm{~nm}$ for TP ${ }^{\mathrm{n}}$-Bzim, $\lambda_{\text {exc }}=515 \mathrm{~nm}$ for TP ${ }^{1+}$-Bzim, $\lambda_{\text {exc }}=525 \mathrm{~nm}$ for TN-2Bzim, $\lambda_{\text {exc }}=460 \mathrm{~nm}$ for TP2Bzim). C) Maximum fluorescence enhancement of the dyes in presence of drewAT in saturation conditions and affinity constants calculated from the fluorimetric titrations using nonlinear furve fitting analysis

\section{Cellular localization}

Next, we investigated the cellular localization of the TPA-TNA dyes and before their biocompatibility was evaluated in Hela cells via CellTiter Glo assay (SI, Table S1). The probes show no significant effect on cell viability at $2 \mu \mathrm{M}$ after $24 \mathrm{~h}$ of incubation and can be used for live-cell imaging. Then the cellular localization of the four probes was examined both in fixed and live HeLa cells and again compared to that of TP-2Bzim which is known to display nuclear localization in fixed cells and mitochondrial localization in live cells. Interestingly $\mathbf{T P}^{1+}$-2Bzim was the only one to exhibit a behaviour similar to that of TP2Bzim but with a significantly lower brightness as directly visualized by the comparison of figures $3 E, F$ and figures $3 G, H$. This correlates well with the weaker DNA affinity and with its photophysical properties determined in solution as the brightness of TP $^{1+}$-2Bzim in drewAT is 4.5 -fold lower than that of TP-2Bzim $\left(\Phi_{\mathrm{F} \times \varepsilon=5363}\right.$ and 23976 respectively) (Table 1). As well excellent contrast is obtained with the two dyes in consistency with their DNA light-up properties (Figure 2, Table $1)$.

On the opposite, the three other dyes (TP-1Bzim, TP ${ }^{n}$-2Bzim TN-2Bzim) did not cause nuclear staining in fixed cells (Figure $3 A, C, I)$ but rather showed a diffuse cytoplasmic staining, thereby confirming either their poor association to DNA neither their low fluorescence enhancement factor, which is not sufficient to cause nuclear labelling in cells. The same cytoplasmic labelling is observed in live cells, but with a spot-like pattern for the two cationic compounds TP-1Bzim and TN-2Bzim (Figure 3B,J) suggesting mitochondrial localization, whereas the signal remains diffuse for the neutral compound $\mathbf{T P}^{\mathrm{n}}$-2Bzim (Figure 3D).

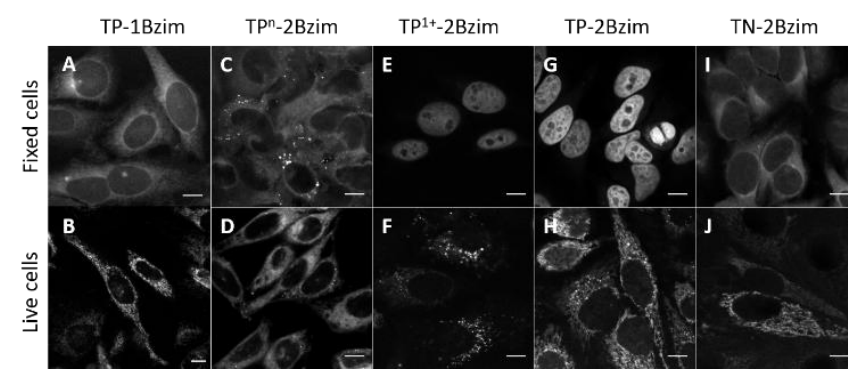

Figure 3. Localization of dyes in fixed $(A, C, E, G, I)$ and live $(B, D, F, H, J)$ Hela cells, TP ${ }^{n}$-2Bzim $\left(\lambda_{\text {exc }}=405 \mathrm{~nm}, \lambda_{\text {em }}=415-700 \mathrm{~nm}\right) ;$ TP $^{1+}$-2Bzim, TP-2Bzim and TN-2Bzim $\left(\lambda_{\text {exc }}=488 \mathrm{~nm}, \quad \lambda_{\mathrm{em}}=500-700 \mathrm{~nm}\right)$, fixation $(3 \%$ paraformaldehyde in PBS for $15 \mathrm{~min}$ ). Scale bar: $10 \mu \mathrm{m}$.

We previously demonstrated that TP-2Bzim is mainly localized in the mitochondria using different organelle trackers in live cells. ${ }^{[16-17]}$ Following a similar approach, co-localization experiments were performed with Mitotracker® Deep Red (MTDR) to confirm the localization of TP-1Bzim, TP ${ }^{1+}$-2Bzim and TN-2Bzim (Figure 4). Excitation at $633 \mathrm{~nm}$ led to the near infra-red fluorescence of MTDR $(650-800 \mathrm{~nm}$, colored in red) while excitation at $488 \mathrm{~nm}$ led to a yellow-red fluorescence typical of the TPA probes (colored in green to allow overlay). The overlay of the pseudo colored images results in a strong yellow color (Figure 4A,B,D) thereby confirming the mitochondrial localization in all cases similarly to what was observed for the parent compound TP-2Bzim (Figure 4C). Spatial co-localization was analyzed using the Van Steensel's method (see Figure S4) and the intensity of co-localization was 
confirmed by calculating Pearson's correlation coefficient $(\approx 0.80$ for, TP-2Bzim and TN-2Bzim). The monocationic TP-1Bzim and TP $^{1+}$-2Bzim showed a Pearson's correlation coefficient with a slightly lower value (0.69-0.7) which might result from difference in emission intensities between the probes and the commercial dye. Taken together these experiments point out that the probes and commercial mitochondrial tracker present similar spatial distribution evidencing mitochondrial sequestration.

Finally, the high two-photon cross-section of TN-2Bzim prompted us to reproduce cellular imaging under two-photon excitation which revealed a bright mitochondrial staining under low laser power (see Figure S5, SI).

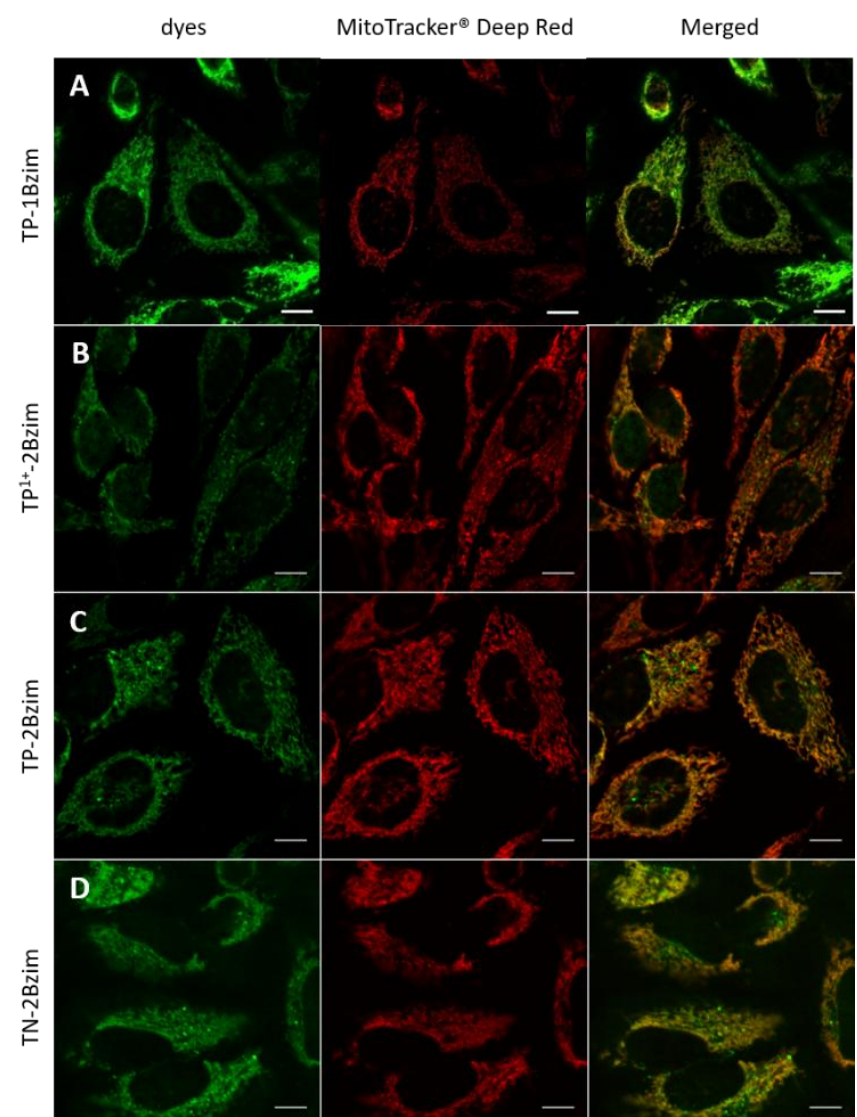

Figure 4. Co-localization experiments with TP-1Bzim (A) TP $^{1+}$-2Bzim (B) TP2Bzim (C) and TN-2Bzim (D) $\left(\lambda_{\mathrm{exc}}=488 \mathrm{~nm}, \lambda_{\mathrm{em}}=500-650 \mathrm{~nm}\right)$. Hela Cells were first incubated with dyes at $2 \mu \mathrm{M}$ for $2 \mathrm{~h}$, then incubated with MitoTracker ${ }^{\circledR}$ Deep Red $\left(100 \mathrm{nM}, 45 \mathrm{~min} ; \lambda_{\mathrm{exc}}=633 \mathrm{~nm}, \lambda_{\mathrm{em}}=650-800 \mathrm{~nm}\right)$. Scale bar: $10 \mu \mathrm{M}$.

As suggested in a number of studies, the mitochondria trapping of dyes can be dependent on the cell line and in particular preferential accumulation in mitochondria of cancer cells has been reported (justified by the higher $\Delta \Psi_{\mathrm{m}}$ in cancer cells vs normal cells). Thus, the cellular localization of $\mathbf{T P}^{1+}-2 \mathrm{Bzim}, \mathrm{TP}$ 2Bzim and TN-2Bzim was assessed in human primary fibroblasts CCD19-Lu (see SI Figure S6-7). The distribution patterns obtained are identical to those observed in Hela cells with the same labelled compartments. Thus, at least from this two-cell lines comparison, it can be inferred that the intracellular distribution of the dyes is not significantly affected by the status of the cell line.

\section{Labelling of mitochondrial DNA}

UV and fluorescence titrations have shown that TP-2Bzim and TP $^{1+}$-2Bzim interact strongly with DNA whilst the TN-2Bzim interacts weakly. As the three compounds stain mitochondria in living cells, we presumed that they could also bind and label mitochondrial DNA (mtDNA) at least for TP-2Bzim and $\mathbf{T P}^{1+}$. 2Bzim. Currently the classical approach to assess mtDNA binding is to carry out colocalization experiments with Picogreen, a commercial mtDNA probe. In live cells Picogreen is able to label both nucleus and mitochondria subcompartment in which it induces dot-like staining (i.e. foci) typical of mtDNA binding. However, this colocalization analysis could not be performed in the present case due to large overlap between the emission spectra of Picogreen and the Bzim dyes. Hence, we adopted an indirect strategy based on the use of 2',3'-dideoxydicitidine (ddC), a well-known inhibitor of mtDNA replication. ${ }^{[24]}$ Treatment by $\mathrm{ddC}$ reduces the amount of mitochondrial DNA, causing a strong decrease in mitochondrial staining intensity. HeLa cells were incubated with ddC for 4 days and then incubated $24 \mathrm{~h}$ with Picogreen or with the Bzim probes. Cells without ddC treatment were used as control for comparison (see Figure 5). The cells treated with ddC did not show any changes in membrane integrity or morphology in comparison to non-treated control cells. As expected Picogreen $\AA$ induces solely nuclear staining in ddC treated cells whereas nuclear and mtDNA labelling are observed in the control non-treated cells (Figures $5 A, E)$, which is clearly indicative of effective blocking of mtDNA replication. Conversely when using the three probes $\left(\mathbf{T P}^{1+}\right.$. 2Bzim, TP-2Bzim and TN-2Bzim) the mitochondrial labelling patterns were not significantly modified by the ddC treatment (compare Figure 5B,C,D and Figure 5F,G,H). These results suggest that the Bzim compounds are not able to reach the mtDNA.

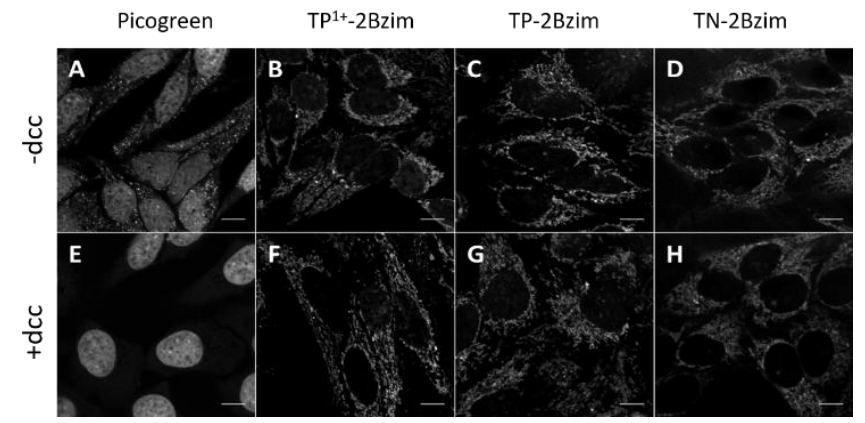

Figure 5. Imaging of live HeLa cells with or without ddC treatment $\left(\lambda_{\mathrm{exc}}=488\right.$ $\left.\mathrm{nm}, \lambda_{\mathrm{em}}=500-800 \mathrm{~nm}\right)$. A, B, C, D) Cells were grown 4 days and stained with dyes: Picogreen $\AA^{8}(1.5 \mu \mathrm{L} / \mathrm{mL}, 1 \mathrm{~h}), \mathrm{TP}^{1+}$-2Bzim, TP-2Bzim or TN-2Bzim (2 $\mu \mathrm{M}, 2$ h). E, F, G, H) After incubation 4 days with ddC at $20 \mu \mathrm{M}$, cells were stained with dyes: Picogreen® $(1.5 \mu \mathrm{L} / \mathrm{mL}, 1 \mathrm{~h})$, TP $^{1+}-2$ Bzim, TP-2Bzim or TN-2Bzim $(2 \mu \mathrm{M}, 2 \mathrm{~h})$. Scale bar: $10 \mu \mathrm{m}$.

In order to confirm this behaviour, we handled experiments with a mitochondrial DNA-lacking cell line (i.e. HeLa rho 0 cells) that represents another useful tool to explore interaction with mtDNA (see Figure S8). ${ }^{[25]}$ Picogreen was used as a positive control and MTDR that anchors covalently in inner membrane proteins was used as a negative control. Both HeLa and HeLa rho 0 cells were incubated with TP $^{1+}$-2Bzim and TP-2Bzim, the best DNA ligands of the series. No changes in the staining patterns were observed with the two dyes, indicating that mitochondria 
labelling is not affected by the absence of mtDNA (Figure $\mathrm{S} 8 \mathrm{~B}, \mathrm{C}, \mathrm{F}, \mathrm{G}$ ) which is also the case of the negative control MTDR (Figure S8D,H). By contrast Picogreen labeled only the nucleus in cells depleted in mtDNA (Fig. S8 E).

The results of these two experiments constitute indirect but strong evidence that the mitochondrial staining induced by Bzim dyes is not resulting from interaction with mtDNA suggesting that the dyes are not able to reach the matrix where multiple copies of $\mathrm{mt}$ DNA are located. Presumably interactions with the complex network of mitochondrial membranes can be envisaged. In support of this, LogD determination indicated values close to 4 for almost all dyes (Table S2 in supporting information) thus revealing the high hydrophobicity of the series. In comparison, the partition coefficient of PicoGreen is significantly lower (calculated $\log D=2.14$ ) which could explain its different behaviour. To further evaluate the dyes affinity for lipidic membranes, fluorimetric titration of TP-2Bzim and TN-2Bzim was carried out with liposomes made of dioleoylphosphaditylcholine (DOPC) (Figure S9). The strong fluorescence increase observed in both cases upon addition of liposomes indicates clearly immobilization of the compounds upon binding to the membrane.

Taken together our data fully support the assumption that the dyes remain sequestered in the inner membrane, which furthermore has a high content in negatively charged phospholipids that may additionally contribute to the trapping through electrostatic attraction.

\section{Mitochondrial Membrane Potential}

The mitochondrial localization of the probes is consistent with their lipophilic cationic nature which strongly suggests that their sequestration is directly dependent on $\Delta \Psi_{\mathrm{m}}$. To further examine this point, we carried out experiments with Carbonyl Cyanide $m$ ChloroPhenyl hydrazone (CCCP), an uncoupling reagent able to depolarize the membrane via inhibition of the oxidative phosphorylation. To this end, HeLa cells were preincubated with the dyes for $2 \mathrm{~h}$ and then treated with CCCP. As shown from Figure 6, TP-2Bzim and $\mathbf{T P}^{1+}$-2Bzim were gradually released from mitochondria and moved to the nuclear compartment that displayed a bright fluorescence signal (Figure $6 \mathrm{~F}-\mathrm{H}, \mathrm{J}-\mathrm{L}$ ). This translocation from mitochondria to nuclear compartment corroborates the strong affinity of the two dyes for duplex DNA shown in vitro and also confirms that small molecular weight compounds diffuse freely through the nuclear membrane in live cells. Interestingly, after removal of CCCP, both dyes translocated back to their initial location site i.e. mitochondria (see SI, Figure S10). This reversible shuttling from mitochondria to nuclear compartment demonstrate firstly that TP-2Bzim and TP $^{1+}$-2Bzim are released from mitochondria when $\Delta \Psi_{m}$ dissipates and reversibly reintegrate their initial mitochondrial localization when $\Delta \Psi_{\mathrm{m}}$ is restablished. This result reveals that the two dyes are indicators of transient variations of $\Delta \Psi_{\mathrm{m}}$ that may be triggered by endogenous or exogenous factors. In particular the strong brightness of TP-2Bzim once in the nucleus could be used as efficient read-out of $\Delta \Psi_{\mathrm{m}}$ perturbation (using for instance flow cytometry). This shuttling from one compartment to another without apparent disturbance of the cell function illustrates the exceptional dynamic of the cells suborganization which may accommodate probe movement. Although the trafficking of macromolecules like mRNA or proteins from the nucleus to the cytoplasm is well documented, the displacement of small molecules/drugs is less well known. Hence fluorescent "shuttling probes" may be useful tools to sense mitochondria dysfunction as well as subtle homeostasis perturbation induced by exogenous and endogenous reagents. In order to confirm the dependence of the dye response towards $\Delta \Psi_{\mathrm{m}}$ variation, we preincubated HeLa cells with the probes and treated them with hydrogen peroxide that simulates oxidative stress and induces cell death by triggering the loss of the mitochondrial membrane potential. As shown from Figure $\mathrm{S} 11$ (SI), TP-2Bzim and TP $^{1+}$-2Bzim relocalized to the nucleus after this treatment thereby acting as detectors of oxidative stress.

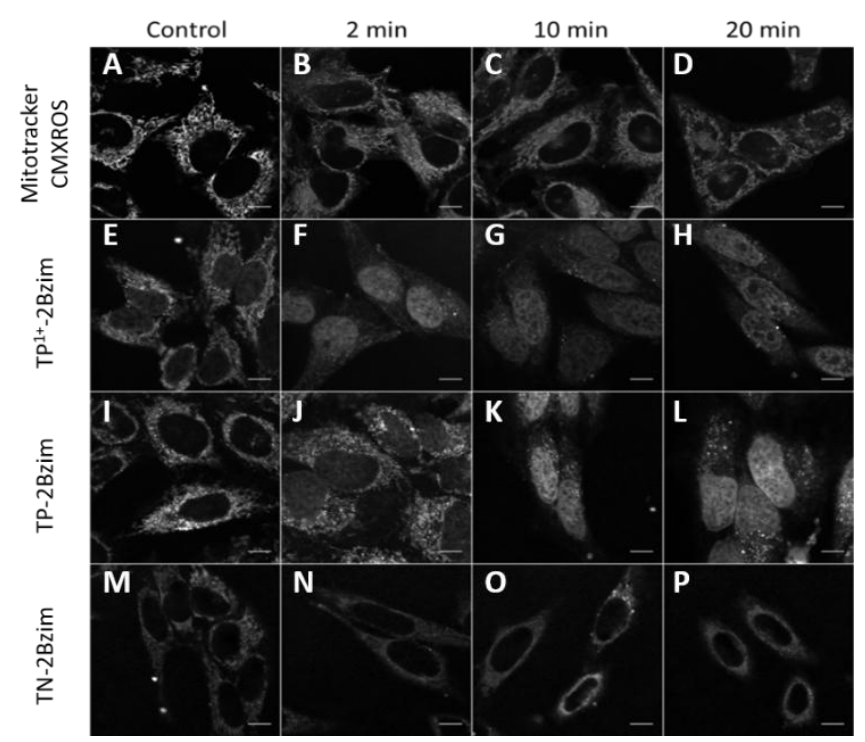

Figure 6. Imaging of live HeLa cells under $\Delta \Psi_{\mathrm{m}}$ perturbation $\left(\lambda_{\text {exc }}=488 \mathrm{~nm}\right.$, $\lambda_{\mathrm{em}}=500-800 \mathrm{~nm}$ ). Cells were stained with dyes at $2 \mu \mathrm{M}, 2 \mathrm{~h}$ : CMXROS (A), TP $^{1+}$-2Bzim (E), TP-2Bzim (I) and TN-2Bzim (M). Cells were stained with dyes at $2 \mu \mathrm{M}, 2 \mathrm{~h}$ and incubated with CCCP at $20 \mu \mathrm{M}, 20$ : CMXROS (B, C, D), TP $^{1+}$-2Bzim (F, G, H), TP-2Bzim (J, K, L) and TN-2Bzim (N, O, P) recorded at 2, 10 and 20 minutes. Scale bar: $10 \mu \mathrm{m}$.

In contrast, for TN-2Bzim a diffuse fluorescence was detected in the cytosol after CCCP addition similarly to what was observed in fixed cells. This indicates that the dye is also released from the mitochondria under $\Delta \Psi_{m}$ dissipation but does not relocalize in the nucleus in consistency with its low affinity towards DNA. Since in this case, the dye translocates from mitochondria to cytosol, the phenomenon is less easy to visualize/image.

We previously reported that translocation of TP-2Bzim from mitochondria to nucleus can be triggered by visible or NIR light upon prolonged irradiation. ${ }^{[17-19]}$ In these conditions apoptosis was induced concomitantly due to ROS production initiated by the dye excited state which further causes strong mitochondria damages and membrane permeabilization. Differently from the present study, this photoinduced translocation phenomenon is irreversible and relevant of a photosensitization effect. Nonetheless, it was of interest to control if TN-2Bzim displays the same photosensitizing activity as its TP counterpart.

Hela cells were incubated with TN-2Bzim and visible light irradiation $(458 \mathrm{~nm}$ ) was carried out for $1 \mathrm{~h}$. As seen from Figure 7, during the course of illumination TN-2Bzim staining shifted progressively from a typical mitochondrial pattern to a diffuse cytoplasmic labelling (Figure 7A vs 7B). Concomitantly this continuous illumination led to blebbing and cellular death through apoptosis as reported for TP-2Bzim. In this case, the 
diffuse cytoplasmic staining of TN-2Bzim is similar to that observed in fixed cells (Figure $3 \mathrm{I}$ ) revealing the leakage of the dye to the cytosol upon $\Delta \psi \mathrm{m}$ dissipation due to apoptosis. Figure $7 \mathrm{C}$ represents an enlarged field of observation after $1 \mathrm{~h}$ of irradiation. Cells outside the irradiated area (delineated in dashed lines) display normal morphology, thus confirming that the blebbing is due to photoactivation of TN-2Bzim.
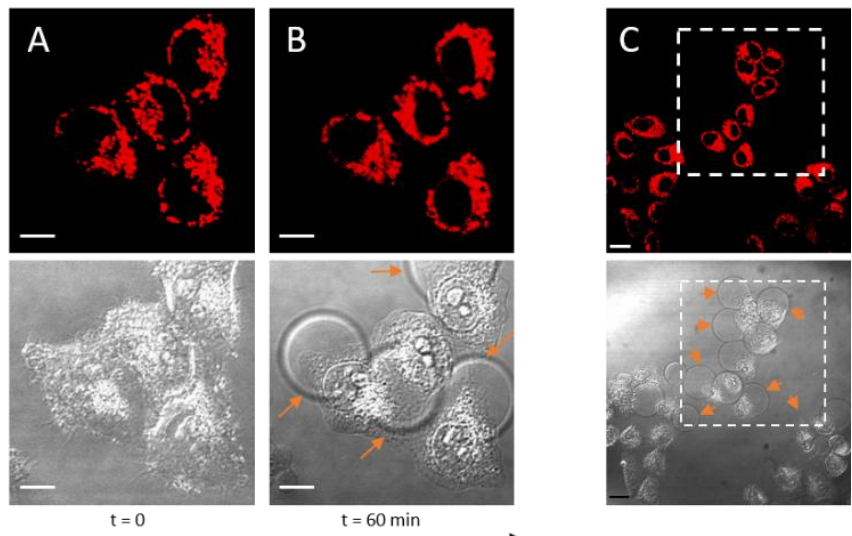

Figure 7. Confocal fluorescence imaging of TN-2Bzim-treated living HeLa cells upon prolonged visible light irradiation $\left(\lambda_{\text {exc }}=458 \mathrm{~nm}, \lambda_{\text {em }}=500-800 \mathrm{~nm}\right)$. Cells were pre-incubated with $2 \mu \mathrm{M}$ TN-2Bzim for $2 \mathrm{~h}$ at $37^{\circ} \mathrm{C}$. Imaging of TN2Bzim A) before continuous irradiation and $B)$ after $1 \mathrm{~h}$ irradiation $\left(\lambda_{\mathrm{exc}}=458\right.$ $\mathrm{nm}$, irradiance $30 \mathrm{~mW} . \mathrm{cm}^{-2}$ ). Corresponding transmission images illustrating the concomitant membrane blebbing (orange arrows) are shown below fluorescence images. Scale bar: $10 \mu \mathrm{m}$. C) Enlarged field of observation for $\mathrm{t}=$ $1 \mathrm{~h}$. The delineated area corresponds to the irradiated area. Scale bar: $20 \mu \mathrm{m}$.

\section{Discussion}

Many dye series have been reported for labelling mitochondria but most display broad structural diversity that makes the establishment of molecular guidelines difficult. We previously developed a series of benzimidazolium vinyltriphenylamine (TPA) dyes and showed that these compounds display a pronounced mitochondria tropism in live cells and may translocate to the nuclear compartment in certain conditions. These subcellular movements can be easily followed by confocal microscopy owing to the fluorogenic property and the exquisite brightness of the TPA compounds. Using this newly synthesized series as prototype, we conducted a study based on subtle structural variations in the aim identifying the factors that influence the dye subcellular behaviour. To this end we explored the chemical space around the parent compound TP-2Bzim to generate a panel of four analogues (TP ${ }^{n}$-2Bzim, TP-1Bzim, TP $^{1+}$-2Bzim, TN-2Bzim) differing by the number of charges, number of vinyl Bzim branches and the nature of the aromatic core. This panel enabled us to study more in depth the structure determinants involved in the mitochondriotropism, mtDNA and nuclear DNA affinity, nuclear localization and translocation phenomenon.

After characterization of the dye properties in vitro (DNA affinity and fluorescence), the systematic comparison of their performances in fixed and live cells led to the following findings: -By adjusting the charge from 0 to 2, we showed that one cationic charge is enough to confer affinity for DNA in vitro, the two monocationic compounds TP-1Bzim and TP $^{1+}$-2Bzim exhibiting similar affinities. This rule can be applied for labelling nuclear DNA in fixed cells but with a notable exception: the monobranched compound (TP-1Bzim) is not able to reach the nuclear compartment evidencing the requirement of a 2branched moiety (TP ${ }^{1+}$-2Bzim) for binding DNA in fixed cells. This indicates that the DNA binding affinities determined in vitro do not fully reflect the performances of dyes in fixed cells, which can be significantly modulated by specific cellular factors. This demonstrates clearly that the binding to nuclear DNA is not solely driven by electrostatics. Finally, the global charge and its distribution has strong impact on the optical properties since both absorption and quantum yield are diminished for the monocationic TP $^{1+}$-2Bzim. In this regard the 2-branched 2+charged compound TP-2Bzim remains the best candidate for nuclear DNA staining combining exceptional brightness and binding affinity.

-The replacement of the triphenylamine (TP) core for the larger trinaphtyl (TN) core abolishes binding to DNA likely by a steric effect preventing insertion in the minor groove, which is corroborated by the incapacity of the dye to label the nuclear compartment in fixed cells. Although this modification increases remarkably the two-photon absorption, the quantum yield and the one-photon absorption are particularly low which might reflect a twisted conformation both in the fundamental and excited state resulting from steric clash between the trinapthyl core and the Bzim moiety. ${ }^{[16 \mathrm{~b}]}$

- In live cells, we observed that all dyes are permeant including the neutral derivative TPn-2Bzim. However, the latter displays a nonspecific cytoplasmic staining similar to that observed in fixed cells. In counterpart the three cationic dyes (TP-1Bzim, TP $^{1+}$. 2Bzim, TN-2Bzim) are all trapped in mitochondria similarly to the parent TP-2Bzim, which again indicate that 1 cationic charge is sufficient for accumulation in mitochondria. This result illustrates the power of the electrostatic gradient created through the mitochondria membrane. However, although the Nernst equation predicts that the concentration of $2+$ vs $1+$ compounds can be 1000 times greater in mitochondria, this is difficult to estimate from the staining intensity that might be modulated by each dye brightness as well as its intramitochondrial localization. Remarkably these results demonstrate that the DNA affinity is not playing a role in the initial trapping phenomena confirming that the mitochondria sequestration is driven essentially by the lipophilic /cationic balance as reported for most probes. ${ }^{[26]}$ In this regard the determination of $\log \mathrm{D}$ indicated that all Bzim dyes have a high liphophilicity $(\log D>3)$, which could be determinant for efficient uptake. Taken together the data show that the ratio $\log \mathrm{D} /$ charge is a valuable indicator whilst it is certainly modulated by other factors inherent to the dye as pointed recently. ${ }^{[11 e, 19]}$

-Since our dyes have high affinity for DNA, we addressed the question of internal localization of the dyes and whether they can bind mitochondrial DNA. Unexpectedly the staining is not modified in Rho (0) cells lacking mtDNA thus showing that none of the cationic dyes were able to label the mtDNA. Again, the high lipophilicity of Bzim dyes and in particular the strong hydrophobicity of the TP or TN cores can contribute to strong embodiment in lipophilic membranes which constitute barriers preventing the access to the matrix. Since even the best DNA stainers of the series (TP-2Bzim, TP $^{1+}$-2Bzim) do not label mitochondrial DNA, this indicates that the DNA affinity is counterbalanced by the complexity of the mitochondria architecture with polarized membranes, interspace membrane 
and high protein/lipid anionic content of the inner membrane. In addition, although many cationic DNA binders are likely to be sequestered fully or partially by mitochondria, our observation indicate that binding to mtDNA is not systematically achieved calling for care in data interpretation. Finally other parameters can play a role both in dye trapping and intramitochondrial localization in line with our recent observation that molecular shape /volume of TPA dyes affect dramatically the passage through the plasma membrane and their subcellular localization. ${ }^{[19]}$

-Finally, the relocalization of TPA-TNA dyes upon $\Delta \Psi_{\mathrm{m}}$ dissipation induced by exogenous stimuli (CCCP, $\mathrm{H}_{2} \mathrm{O}_{2}$ ) indicates the strong dependence on the membrane polarization status. However, in contrast to mitochondria trapping and internal localization, the spatial redistribution is directly correlated to their cellular localization in fixed cells as translocation to nuclear compartment was observed only for the two nuclear stainers in fixed cells (TP ${ }^{1+}$-2Bzim, TP-2Bzim) whereas leakage to the cytosol was seen for TN-2Bzim. This reveals that a reasonable level of DNA affinity should be achieved to allow mitochondria to nuclear translocation. Interestingly, the phenomenon is reversible and the TPA dyes reintegrate their mitochondrial localization when the membrane potential is reestablished. This points out to the high dynamics of the cellular subcompartments which enable drug/small molecules movements and exchanges but has been poorly explored so far.

Finally and interestingly, translocation of TPA-TNA occurs both in conditions of transient loss of $\Delta \Psi_{\mathrm{m}}$ induced by physiological circumstances or of long lasting /permanent $\Delta \Psi_{\mathrm{m}}$ dissipation induced by light and associated with apoptosis, which altogether make them valuable indicators of membrane potential variations.

\section{Conclusion}

The cationic character of DNA-interactive dyes confers both nuclear DNA-labelling potential and mitochondria-tropism. However, in live cells, the partitioning between the nuclear and mitochondrial compartments is governed by a number of other factors like lipophilicity and subtle differences in molecular shape and charge distribution. Hence the cellular behaviour of dyes is difficult to predict and to rationalize. For instance, Picogreen distributes between mitochondrial and nucleus whereas the Bzim dyes have exclusive subcompartment localization (nucleus vs mitochondria). In addition, the precise localization of dyes inside mitochondria is rendered difficult by the complex architecture of this subcompartment and the possible partitioning between membranes, interspace, matrix and mtDNA, which should be taken into consideration in the data interpretation. In that sense, our structure activity study focused on the Bzim dyes illustrates the challenge for finding the trade-off between the multiple requirements for a precise targeted-localization of small molecules while retaining brightness and fluorogenic properties for optimized imaging.

Ultimately our study shows that targeted-fluorescent dyes represent invaluable chemical probes to study the dynamic nature of compartments, yet poorly understood, and to provide deeper understanding of intracellular trafficking of drugs and hence of their cellular activity.

\section{Experimental Section}

General experimental procedures, analysis and instrumental details are provided in the Supporting Information.

TP ${ }^{n}$-2Bzim and TP-2Bzim have been previously reported in the literature and were synthesized following the reported protocols. The spectral data were in agreement with the literature values. ${ }^{[16 \mathrm{~b}]}$

Synthesis of triphenylamine 1: To a solution of 4-formyltriphenylamine (100 mg, $0.37 \mathrm{mmol}, 1 \mathrm{eq})$ and and ( $N$-methyl benzimidazole)methyltriphenylphosphonium chloride $(244 \mathrm{mg}, 0.55 \mathrm{mmol}, 1.5 \mathrm{eq})$ in a mixture of THF/EtOH (2 mL, 1:1, v/v) was added 1,8 Diazabicyclo[5.4.0]undec-7-ene, DBU (164 $\mu \mathrm{L}, 1.10 \mathrm{mmol}, 3.0$ eq.). The solution was stirred overnight at room temperature in dark. Solvents were evaporated and the crude product was purified by column chromatography over silica gel (cyclohexane/ EtOAc 6:4) to afford the desired compound 1 as a yellow powder (68.8 mg, $47 \%$ ). m.p. 141 $143^{\circ} \mathrm{C} .{ }^{1} \mathbf{H}$ NMR $\left(300 \mathbf{~ M H z}, \mathbf{C D C l}_{3}\right) \delta(\mathrm{ppm}) 7.92(\mathrm{~d}, J=16.0 \mathrm{~Hz}, 1 \mathrm{H})$, $7.82-7.69(\mathrm{~m}, 1 \mathrm{H}, \mathrm{Ar}-\mathrm{H}), 7.47(\mathrm{~d}, J=8.5 \mathrm{~Hz}, 2 \mathrm{H}, \mathrm{Ar}-\mathrm{H}), 7.37-7.21(\mathrm{~m}$, $\mathrm{CH}=\mathrm{CH}, 8 \mathrm{H}, \mathrm{Ar}-\mathrm{H}), 7.18-7.02(\mathrm{~m}, 8 \mathrm{H}), 6.96(\mathrm{~d}, \mathrm{~J}=16.0 \mathrm{~Hz}, 1 \mathrm{H}$, $\mathrm{CH}=\mathrm{CH}$ ), $3.85\left(\mathrm{~s}, 3 \mathrm{H}, \mathrm{CH}_{3}\right) \cdot{ }^{13} \mathbf{C}$ NMR (75 MHz, $\left.\mathbf{C D C l}_{3}\right) \delta 151.7\left(\mathrm{C}_{\mathrm{q}}\right)$, $148.9\left(\mathrm{C}_{\mathrm{q}}\right), 147.3\left(\mathrm{C}_{\mathrm{q}}\right), 143.3\left(\mathrm{C}_{\mathrm{q}}\right), 137.1(\mathrm{CH}), 136.2\left(\mathrm{C}_{\mathrm{q}}\right), 130.3(\mathrm{CH})$, $129.7\left(\mathrm{C}_{\mathrm{q}}\right), 129.5(\mathrm{CH}), 128.4(\mathrm{CH}), 125.2(\mathrm{CH}), 123.7(\mathrm{CH}), 122.7(\mathrm{CH})$, $122.5(\mathrm{CH}), 119.3(\mathrm{CH}), 110.7(\mathrm{CH}), 109.2(\mathrm{CH}), 29.9\left(\mathrm{CH}_{3}\right)$. HRMS (ESI): $\mathrm{m} / \mathrm{z}$ calcd for $\mathrm{C}_{28} \mathrm{H}_{24} \mathrm{~N}_{3}: 402.1970[\mathrm{M}+\mathrm{H}]^{+}$, found: 402.1968

Synthesis of TP-1Bzim: To a solution of triphenylamine $1(13.8 \mathrm{mg}$, $0.03 \mathrm{mmol}, 1 \mathrm{eq})$ in DMF $(0.5 \mathrm{~mL})$ was added Mel $(0.2 \mathrm{~mL})$ and the mixture was stirred at room temperature overnight. The reaction mixture was concentrated to dryness. The crude residue was dissolved in a minimal amount of methanol and precipitated by addition of diethyl ether, affording in quantative yield the desired compound as a yellow solid (18.7 mg, quantitative yield). m.p. > 260 ${ }^{\circ} \mathrm{C} .{ }^{1} \mathrm{H}$ NMR (300 MHz, DMSO) $\delta 8.02$ (dd, $J=6.0,3.0 \mathrm{~Hz}, 2 \mathrm{H}, \mathrm{Ar}-\mathrm{H}), 7.79$ (d, $J=8.5 \mathrm{~Hz}, 2 \mathrm{H}, \mathrm{Ar}-\mathrm{H}), 7.74$ (d, $J=$ $16.5 \mathrm{~Hz}, 1 \mathrm{H}, \mathrm{CH}=\mathrm{CH}$ ), 7.67 (dd, $J=6.0,3.0 \mathrm{~Hz}, 1 \mathrm{H}, \mathrm{Ar}-\mathrm{H}), 7.39$ (t, $J=$ $7.5 \mathrm{~Hz}, 4 \mathrm{H}, \mathrm{Ar}-\mathrm{H}), 7.33$ (d, $J=16.5 \mathrm{~Hz}, 2 \mathrm{H}, \mathrm{CH}=\mathrm{CH}), 7.16(\mathrm{~m}, 6 \mathrm{H}, \mathrm{Ar}-\mathrm{H})$, $7.20-7.12(\mathrm{~d}, J=8.5 \mathrm{~Hz}, 2 \mathrm{H}, \mathrm{Ar}-\mathrm{H}), 4.11\left(\mathrm{~s}, 3 \mathrm{H}, \mathrm{CH}_{3}\right) \cdot{ }^{13} \mathrm{C}$ NMR (75 MHz, DMSO) $\delta 150.1\left(\mathrm{C}_{\mathrm{q}}\right), 148.7\left(\mathrm{C}_{\mathrm{q}}\right), 146.2\left(\mathrm{C}_{\mathrm{q}}\right), 146.2(\mathrm{CH}), 132.0\left(\mathrm{C}_{\mathrm{q}}\right)$, $130.2(\mathrm{CH}), 129.9(\mathrm{CH}), 127.2\left(\mathrm{C}_{\mathrm{q}}\right), 126.3(\mathrm{CH}), 125.4(\mathrm{CH}), 124.6(\mathrm{CH})$, $120.6(\mathrm{CH}), 112.8(\mathrm{CH}), 104.7(\mathrm{CH}), 32.9\left(\mathrm{CH}_{3}\right)$. HRMS (ESI+) m/z calcd for $\mathrm{C}_{29} \mathrm{H}_{26} \mathrm{~N}_{3}$ : 416.2138 [M-I] $]^{+}$, found: 416.2127 .

Synthesis of aldehyde 2: To a solution of 4,4'-bisformyltriphenylamine (50.0 mg, $165.9 \mu \mathrm{mol}, 3.0$ eq.) and ( $N$-methyl benzimidazole)methyltriphenylphosphonium chloride $(24.5 \mathrm{mg}, 55.3 \mu \mathrm{mol}, 1.0$ eq.) in a mixture of THF/EtOH $(0.82 \mathrm{~mL}, 1: 1, \mathrm{v} / \mathrm{v})$ was added 1,8Diazabicyclo[5.4.0]undec-7-ene, DBU (16.5 $\mu \mathrm{L}, 111 \mu \mathrm{mol}, 2.0$ eq.). The solution was stirred overnight at room temperature in dark. Solvents were concentrated and the crude residue was purified by column chromatography over silica gel (cyclohexane/EtOAc 7:3) to afford the desired compound 2 as a yellow powder (20.0 mg, 84\%). m.p. 115$122^{\circ} \mathrm{C}$. ${ }^{1} \mathrm{H}$ NMR (300 MHz, $\left.\mathbf{C D C l}_{3}\right) \delta=9.84(\mathrm{~s}, 1 \mathrm{H}, \mathrm{CHO}), 7.94(\mathrm{~d}, J=$ $16.0 \mathrm{~Hz}, 1 \mathrm{H}, \mathrm{CH}=\mathrm{CH}), 7.79-7.74(\mathrm{~m}, 1 \mathrm{H}, \mathrm{Ar}-\mathrm{H}), 7.72(\mathrm{~d}, J=8.5 \mathrm{~Hz}, 2 \mathrm{H}$, Ar-H), 7.56 (d, J=8.5 Hz, 2H; Ar-H), $7.41-7.27(\mathrm{~m}, 5 \mathrm{H}, \mathrm{Ar}-\mathrm{H}), 7.24-$ $7.14(\mathrm{~m}, 5 \mathrm{H}, \mathrm{Ar}-\mathrm{H}), 7.11(\mathrm{~d}, J=8.5 \mathrm{~Hz}, 2 \mathrm{H}, \mathrm{Ar}-\mathrm{H}), 7.04(\mathrm{~d}, J=16.0 \mathrm{~Hz}$, $1 \mathrm{H}, \mathrm{CH}=\mathrm{CH}$ ), 3.87 (s, 3H, CH$)_{3}{ }^{13} \mathbf{C}$ NMR (75 MHz, $\left.\mathbf{C D C l}_{3}\right) \delta=190.5$ $(\mathrm{CH}), 152.8\left(\mathrm{C}_{\mathrm{q}}\right), 151.1\left(\mathrm{C}_{\mathrm{q}}\right), 146.9\left(\mathrm{C}_{\mathrm{q}}\right), 145.9\left(\mathrm{C}_{\mathrm{q}}\right), 143.1\left(\mathrm{C}_{\mathrm{q}}\right), 136.2$ $(\mathrm{CH}), 136.2\left(\mathrm{C}_{\mathrm{q}}\right), 132.2\left(\mathrm{C}_{\mathrm{q}}\right), 131.3(\mathrm{CH}), 129.9(\mathrm{CH}), 129.8\left(\mathrm{C}_{\mathrm{q}}\right), 128.5$ $(\mathrm{CH}), 126.6(\mathrm{CH}), 125.5(\mathrm{CH}), 125.4(\mathrm{CH}), 122.7(\mathrm{CH}), 122.5(\mathrm{CH}), 120.5$ (CH), $119.2(\mathrm{CH}), 112.2(\mathrm{CH}), 109.2(\mathrm{CH}), 29.7\left(\mathrm{CH}_{3}\right)$. HRMS (ESI $\left.{ }^{+}\right): \mathrm{m} / \mathrm{z}$ calcd for $\mathrm{C}_{29} \mathrm{H}_{24} \mathrm{~N}_{3} \mathrm{O}: 430.1920[\mathrm{M}+\mathrm{H}]^{+}$, found: 430.1919 .

Synthesis of TP $^{1+}$-2Bzim: To a solution of aldehyde 2 (50 mg, 116.5 $\mu \mathrm{mol}, 1.0$ eq.) and 1,2,3-trimethyl-1/Hbenzo[d]imidazole-3-ium iodide (33.5 mg, $116.5 \mu \mathrm{mol}, 1.0$ eq.) in $\mathrm{EtOH}(4 \mathrm{~mL})$ was added piperidine (23 $\mu \mathrm{L}, 233 \mu \mathrm{mol}, 2.0$ eq.). The mixture was stirred overnight at $80^{\circ} \mathrm{C}$. The black solution was concentrated and the crude product was purified by column chromatography over silica gel $\left(\mathrm{CH}_{2} \mathrm{Cl}_{2} / \mathrm{EtOH} 98: 2\right)$ to give the desired compound (31 mg, 38\%) as orange powder. m.p. $>260^{\circ} \mathrm{C}$. ${ }^{1} \mathbf{H}$ 
NMR (300 MHz, DMSO) $\delta=8.03(\mathrm{dd}, J=6.0,3.0 \mathrm{~Hz}, 2 \mathrm{H}, \mathrm{Ar}-\mathrm{H}), 7.88-$ $7.74(\mathrm{~m}, 6 \mathrm{H}, \mathrm{Ar}-\mathrm{H}), 7.67$ (dd, $J=6.0,3.0 \mathrm{~Hz}, 2 \mathrm{H}, \mathrm{Ar}-\mathrm{H}), 7.63-7.50(\mathrm{~m}$, $2 \mathrm{H}, \mathrm{Ar}-\mathrm{H}), 7.48-7.34(\mathrm{~m}, 4 \mathrm{H}, \mathrm{Ar}-\mathrm{H}), 7.23-7.10(\mathrm{~m}, 9 \mathrm{H}, \mathrm{Ar}-\mathrm{H}), 4.13(\mathrm{~s}$ $6 \mathrm{H}, \mathrm{CH}_{3}$ ), $3.92\left(\mathrm{~s}, 3 \mathrm{H}, \mathrm{CH}_{3}\right) .{ }^{13} \mathrm{C}$ NMR (75 MHz, DMSO) $\delta=151.1\left(\mathrm{C}_{\mathrm{q}}\right)$, $149.5\left(\mathrm{C}_{\mathrm{q}}\right), 148.6\left(\mathrm{C}_{\mathrm{q}}\right), 146.7\left(\mathrm{C}_{\mathrm{q}}\right), 146.0\left(\mathrm{C}_{\mathrm{q}}\right), 145.9(\mathrm{CH}), 142.8\left(\mathrm{C}_{\mathrm{q}}\right)$, $136.0\left(\mathrm{C}_{\mathrm{q}}\right), 135.1(\mathrm{CH}), 131.9\left(\mathrm{C}_{\mathrm{q}}\right), 131.6\left(\mathrm{C}_{\mathrm{q}}\right), 130.2(\mathrm{CH}), 130.0(\mathrm{CH})$, $128.9(\mathrm{CH}), 128.0\left(\mathrm{C}_{\mathrm{q}}\right), 126.3(\mathrm{CH}), 125.7(\mathrm{CH}), 125.0(\mathrm{CH}), 124.3(\mathrm{CH})$, $122.0(\mathrm{CH}), 121.9(\mathrm{CH}), 121.8(\mathrm{CH}), 118.3(\mathrm{CH}), 113.3(\mathrm{CH}), 112.8(\mathrm{CH})$, $110.1(\mathrm{CH}), 105.2(\mathrm{CH}), 32.9\left(\mathrm{CH}_{3}\right), 29.6\left(\mathrm{CH}_{3}\right)$. HRMS (ESI+) m/z calcd for $\mathrm{C}_{39} \mathrm{H}_{34} \mathrm{~N}_{5}: 572.2814[\mathrm{M}-]^{+}$, found: 572.2815 .

Synthesis of dialdehyde 3 : In dry and degassed toluene $(30.0 \mathrm{~mL})$ were introduced $\mathrm{Pd}(\mathrm{OAc})_{2}(30.0 \mathrm{mg}, 125.0 \mu \mathrm{M}, 5 \mathrm{~mol} \%)$ and $\mathrm{P}(t-\mathrm{Bu})_{3}(1.2 \mathrm{~mL}$, $10 \%$ in hexanes w/w, $7.0 \mathrm{mmol}, 12 \mathrm{~mol} \%$ ). After $15 \mathrm{~min}$ stirring, 6-bromo2-naphthaldehyde (2.3 g, $7.0 \mathrm{mmol}, 2.8 \mathrm{eq}$.), 2-aminonaphthalene (500 $\mathrm{mg}, 2.5 \mathrm{mmol}, 1.0$ eq.) and $\mathrm{Cs}_{2} \mathrm{CO}_{3}(2.0 \mathrm{~g}, 6.25 \mathrm{mmol}, 2.5$ eq.). The solution was refluxed $48 \mathrm{~h}$, cooled to room temperature and diluted with $\mathrm{CH}_{2} \mathrm{Cl}_{2}(100 \mathrm{~mL})$. The crude mixture was filtered through a celite $\AA$ pad, concentrated and purified by column chromatography over silica gel (cyclohexane/ $\mathrm{CH}_{2} \mathrm{Cl}_{2} 2: 1$ to $\left.1: 2\right)$ to afford product $3(610.0 \mathrm{mg}, 38 \%$ ) as a yellow powder. m.p. $135-142^{\circ} \mathrm{C} .{ }^{1} \mathbf{H}$ NMR (300 $\left.\mathbf{M H z}, \mathbf{C D C l}_{3}\right) \delta=10.12$ (s, $2 \mathrm{H}, \mathrm{CHO}$ ), 8.28 (s, 2H, Ar-H), 7.94-7.85 (m, 6H, Ar-H), 7.66 (d, J = 9.0 $\mathrm{Hz}, 2 \mathrm{H}, \mathrm{Ar}-\mathrm{H}$ ), 7.54 (s, 2H, Ar-H), 7.49-7.45 (m, 4H, Ar-H), 7.38 (dd, J= 9.0, $1.5 \mathrm{~Hz}, 1 \mathrm{H}, \mathrm{Ar}-\mathrm{H}) .{ }^{13} \mathbf{C}$ NMR (75 MHz, $\left.\mathbf{C D C l}_{3}\right) \delta=192.0(\mathrm{CH}), 147.9$ $\left(\mathrm{C}_{\mathrm{q}}\right), 144.2\left(\mathrm{C}_{\mathrm{q}}\right), 137.9\left(\mathrm{C}_{\mathrm{q}}\right), 134.5\left(\mathrm{C}_{\mathrm{q}}\right), 134.1(\mathrm{CH}), 133.3\left(\mathrm{C}_{\mathrm{q}}\right), 131.3$ $\left(\mathrm{C}_{\mathrm{q}}\right), 131.0(\mathrm{CH}), 130.0(\mathrm{CH}), 129.4\left(\mathrm{C}_{\mathrm{q}}\right), 128.1(\mathrm{CH}), 127.9(\mathrm{CH}), 127.5$ $(\mathrm{CH}), 126.9(\mathrm{CH}), 125.9(\mathrm{CH}), 125.3(\mathrm{CH}), 125.0(\mathrm{CH}), 124.0(\mathrm{CH}), 123.5$ $(\mathrm{CH}), 120.1(\mathrm{CH}) . \mathbf{M S}(\mathrm{ESI}+) \mathrm{m} / \mathrm{z} 452.2[\mathrm{M}+\mathrm{H}]^{+}$.

Synthesis of TN-2Bzim: To a solution of dialdehyde $3(40.0 \mathrm{mg}, 89$ $\mu \mathrm{mol}, 1.0$ eq.) and 1,2,3-trimethyl-1 Hbenzo[d]imidazole-3-ium iodide (51 $\mathrm{mg}, 180 \mu \mathrm{mol}, 2.0$ eq.) in $\mathrm{EtOH}(4.0 \mathrm{~mL})$ was added piperidine $(35.0 \mu \mathrm{L}$, $356 \mu \mathrm{mol}, 4.0$ eq.). The mixture was stirred overnight at $80^{\circ} \mathrm{C}$. The reaction mixture was cooled to room temperature, then the desired compound was precipitated in $\mathrm{Et}_{2} \mathrm{O}$ to afford the desired compound (27 mg; $31 \%$ ) as a dark powder. m.p. > 260 ${ }^{\circ} \mathrm{C} .{ }^{1} \mathbf{H}$ NMR (300 $\mathbf{M H z}$, DMSO) $\delta$ $=8.37(\mathrm{~s}, 2 \mathrm{H}, \mathrm{Ar}-\mathrm{H}), 8.14(\mathrm{~d}, J=8.5 \mathrm{~Hz}, 2 \mathrm{H}, \mathrm{Ar}-\mathrm{H}), 8.09-7.98(\mathrm{~m}, 10 \mathrm{H}$, Ar-H), $7.92(\mathrm{~d}, J=9.0 \mathrm{~Hz}, 2 \mathrm{H}, \mathrm{Ar}-\mathrm{H}), 7.83-7.81(\mathrm{~m}, 1 \mathrm{H}, \mathrm{Ar}-\mathrm{H}), 7.71-7.62$ $(\mathrm{m}, 9 \mathrm{H}, \mathrm{Ar}-\mathrm{H}), 7.55-7.38(\mathrm{~m}, 5 \mathrm{H}, \mathrm{Ar}-\mathrm{H}), 4.20\left(\mathrm{~s}, 12 \mathrm{H}, \mathrm{CH}_{3}\right) .{ }^{13} \mathrm{C}$ NMR (126 MHz, DMSO) $\delta=148.3\left(\mathrm{C}_{\mathrm{q}}\right), 146.4(\mathrm{CH}), 146.4\left(\mathrm{C}_{\mathrm{q}}\right), 144.1\left(\mathrm{C}_{\mathrm{q}}\right)$, $135.5\left(\mathrm{C}_{\mathrm{q}}\right), 134.1\left(\mathrm{C}_{\mathrm{q}}\right), 132.1\left(\mathrm{C}_{\mathrm{q}}\right), 131.0\left(\mathrm{C}_{\mathrm{q}}\right), 130.7(\mathrm{CH}), 130.7\left(\mathrm{C}_{\mathrm{q}}\right)$, $130.4(\mathrm{CH}), 129.9(\mathrm{CH}), 129.5\left(\mathrm{C}_{\mathrm{q}}\right), 127.9(\mathrm{CH}), 127.7(\mathrm{CH}), 127.3(\mathrm{CH})$, $126.7(\mathrm{CH}), 126.5(\mathrm{CH}), 125.6(\mathrm{CH}), 125.1(\mathrm{CH}), 124.7(\mathrm{CH}), 124.3(\mathrm{CH})$, $122.6(\mathrm{CH}), 119.7(\mathrm{CH}), 113.0(\mathrm{CH}), 107.3(\mathrm{CH}), 33.0\left(\mathrm{CH}_{3}\right)$. HRMS (ESI+) $\mathrm{m} / \mathrm{z}$ calcd for $\mathrm{C}_{52} \mathrm{H}_{43} \mathrm{~N}_{5} \mathrm{l}:$ 864.2563: [M-I] ${ }^{+}$, found: 864.2548 .

\section{Acknowledgements}

We are very grateful to Dr. Marie-Noelle Soler and Laetitia Besse from the photonic microscopy platform (Institut Curie, CNRS UMS2016, INSERM U43, Université Paris-Saclay, Orsay, France) for technical assistance in the use of the Leica confocal SP5 system. We are grateful to Prof. Wiesner and Ms. Bust from Institute for Vegetative Physiology, University of Cologne, Germany and Prof. Hayashi from University of Tsukuba, Japan for providing the mitochondrial DNA-lacking HeLa rhoO cells. This work has benefited from the facilities and expertise of the Small Molecule Mass Spectrometry platform of ICSN (Centre de Recherche de Gif - www.icsn.cnrs-gif.fr) as well as the facilities of TechMedIII (UMS3286). We wish to thank Dr. Nicolas Tsapis for providing the liposomes of DOPC.

Keywords: Fluorescent probes • Chemical Biology • Organelle imaging probes $\cdot$ Mitochondria •
H. Zhu, J. Fan, J. Du, X. Peng, Acc. Chem. Res. 2016, 49, 2115-2126; b) P. Gao, W. Pan, N. Li, B. Tang, Chem. Sci. 2019, 10, 6035-6071; c) W. Xu, Z. Zeng, J.-H. Jiang, Y.-T. Chang, L. Yuan, Angew. Chem. Int. Ed. 2016, 55, 13658-13699.

[2] O. Kepp, L. Galluzzi, M. Lipinski, J. Yuan, G. Kroemer, Nat. Rev. Drug Disc. 2011, 10, 221-237.

[3] a) G. Kroemer, Oncogene 2006, 25, 4630-4632; b) D. F. Suen, K. L. Norris, R. J. Youle, Genes Dev 2008, 22, 1577-1590; c) S. Fulda, L. Galluzzi, G. Kroemer, Nat. Rev. Drug Disc. 2010, 9, 447 464.

[4] M. Di Carlo, D. Giacomazza, P. Picone, D. Nuzzo, P. L. San Biagio, Free Radic Res 2012, 46, 1327-1338.

F. Liu, J. Lu, A. Manaenko, J. Tang, Q. Hu, Aging Dis 2018, 9 , 924-937.

6] S. I. Dikalov, D. G. Harrison, Antioxid Redox Signal 2014, 20, 372 382.

[7] A. R. Sarkar, C. H. Heo, L. Xu, H. W. Lee, H. Y. Si, J. W. Byun, H. M. Kim, Chem. Sci. 2016, 7, 766-773

[8] S. W. Perry, J. P. Norman, J. Barbieri, E. B. Brown, H. A. Gelbard BioTechniques 2011, 50, 98-115.

[9] J. D. Ly, D. R. Grubb, A. Lawen, Apoptosis 2003, 8, 115-128.

[10] B. A. D. Neto, J. R. Corrêa, R. G. Silva, RSC Advances 2013, 3 5291.

[11] a) M. P. Murphy, Biochim. Biophys. Acta 2008, 1777, 1028-1031; b) Meredith F Ross, Tracy A Prime, I Abakumova, Andrew M. James, Carolyn M. Porteous, Robin A. J. Smith, Michael P. Murphy, Biochem. J. 2008, 411, 633-645; c) M. F. Ross, T. Da Ros, F. H. Blaikie, T. A. Prime, C. M. Porteous, Severina, II, V. P. Skulachev, H. G. Kjaergaard, R. A Smith, M. P Murphy, Biochem J 2006, 400, 199-208; d) H. C. Ong, Z. Hu, J. T. S. Coimbra, M. J. Ramos, O. L. Kon, B. Xing, E. K. L. Yeow, P. A. Fernandes, F. Garcia, Inorg Chem 2019, 58, 8293-8299; e) Z. Hu, Y. Sim, O. L. Kon, W. H. Ng, A. J. Ribeiro, M. J. Ramos, P. A. Fernandes, R. Ganguly, B. Xing, F. Garcia, E. K. Yeow, Bioconjug Chem 2017 28, 590-599; f) H. C. Bertrand, F. Garcia, C. Policar, N. Delsuc, K Medjoubi, A. Somogyi, H. C. Ong, L. Henry, G. Schanne, ChemRxiv 2021.

Groemer, L. Galluzzi, C. Brenner, Physiol Rev 2007, 87, 99 163; bL. F. Yousif, K. M. Stewart, S. O. Kelley, ChemBioChem 2009, 10, 1939-1950

[13] S. Samanta, Y. He, A. Sharma, J. Kim, W. Pan, Z. Yang, J. Li, W. Yan, L. Liu, J. Qu, J. S. Kim, Chem 2019, 5, 1697-1726.

[14] S. T. Smiley, M. Reers, C. Mottola-Hartshorn, M. Lin, A. Chen, T. W. Smith, G. D. Steele, L. B. Chen, Proc. Natl. Acad. Sci. U. S. A. 1991, 88, 3671-3675.

[15] a) X. Li, M. Tian, G. Zhang, R. Zhang, R. Feng, L. Guo, X. Yu, N. Zhao, X He Anal Chem 2017, 89, 3335-3344; b) H Seki, S. Onishi, N. Asamura, Y. Suzuki, J. Kawamata, D. Kaneno, S. Hadano, S. Watanabe, Y. Niko, J. Mater. Chem. B 2018, 6, 7396 7401 ; c) M. Tian, J. Sun, B. Dong, W. Lin, Angew. Chem. Int. Ed 2018, 57, 16506-16510; d) M. Tian, J. Sun, B. Dong, W. Lin, Sens. Actuators B Chem. 2019, 292, 16-23; e) H. Moritomo, K. Yamada, Y. Kojima, Y. Suzuki, S. Tani, H. Kinoshita, A. Sasaki, S. Mikuni, M. Kinjo, J. Kawamata, Cell Struct. Funct. 2014, 39, 125-133. a) C. Allain, F. Schmidt, R. Lartia, G. Bordeau, C. FioriniDebuisschert, F Charra P Tauc M-P. Teulade-Fichou, ChemBioChem 2007, 8, 424-433; b) B. Dumat, G. Bordeau, E. Faurel-Paul, F. Mahuteau-Betzer, N. Saettel, G. Metge, C. FioriniDebuisschert, F. Charra, M. P. Teulade-Fichou, J. Am. Chem. Soc 2013, 135, 12697-12706.

[17] R. Chennoufi, H. Bougherara, N. Gagey-Eilstein, B. Dumat, E Henry, F. Subra, F. Mahuteau-Betzer, P. Tauc, M. P. TeuladeFichou, E. Deprez, Chem. Commun. 2015, 51, 14881-14884

[18] R. Chennoufi, H. Bougherara, N. Gagey-Eilstein, B. Dumat, E. Henry, F. Subra, S. Bury-Mone, F. Mahuteau-Betzer, P. Tauc, M. P. Teulade-Fichou, E. Deprez, Sci. Rep. 2016, 6, 21458.

[19] R. Chennoufi, N.-D. Trinh, F. Simon, G. Bordeau, D. Naud-Martin A. Moussaron, B. Cinquin, H. Bougherara, B. Rambaud, P. Tauc C. Frochot, M.-P. Teulade-Fichou, F. Mahuteau-Betzer, E. Deprez, Sci. Rep. 2020, 10, 6881.

[20] W. C. Huang, T. Y. Tseng, Y. T. Chen, C. C. Chang, Z. F. Wang C. L. Wang, T. N. Hsu, P. T. Li, C. T. Chen, J. J. Lin, P. J. Lou, T. C. Chang, Nucleic Acids Res. 2015, 43, 10102-10113.

[21] D. L. Prole, P. F. Chinnery, N. S. Jones, J Biol Chem 2020, 295 17588-17601.

[22] G. Bordeau, R. Lartia, G. Metge, C. Fiorini-Debuisschert, F Charra, M.-P. Teulade-Fichou, J. Am. Chem. Soc. 2008, 130, 16836-16837.

[23] G. Cosa, K. S. Focsaneanu, J. R. McLean, J. P. McNamee, J. C. Scaiano, Photochem. Photobiol. 2001, 73, 585-599. J. L. Martin, C. E. Brown, N. Matthews-Davis, J. E. Reardon, Antimicrob Agents Chemother 1994, 38, 2743-2749.

[25] a) M. P. King, G. Attardi, in Methods Enzymol., Vol. 264, Academic Press, 1996, pp. 304-313; b) J. Hayashi, S. Ohta, A. Kikuchi, M. Takemitsu, Y. Goto, I. Nonaka, Proc. Natl. Acad. Sci. U. S. A 1991, 88, 10614; c) M. Schauen, H. T. Hornig-Do, S. Schomberg 
G. Herrmann, R. J. Wiesner, Free Radic Biol Med 2007, 42, 499 509. [26] S. Wisnovsky, E. K. Lei, S. R. Jean, S. O. Kelley, Cell Chem Biol
2016, 23, 917-927. 


\section{Entry for the Table of Contents}
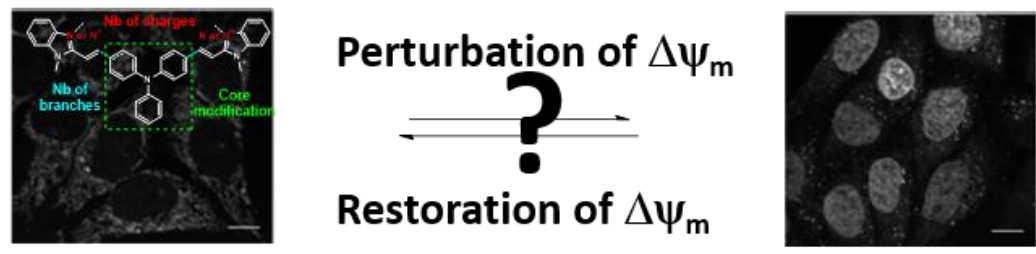

Fluorescent probes based on a triphenylamine core have been designed and synthesized as cellular imaging tools for monitoring the mitochondrial status. This study was carried out to decipher the mechanism of relocalization from mitochondria to nucleus under mitochondrial membrane depolarisation. 